\title{
Milyen szerepet játszanak a nyelvjárások a német nemzetiségi oktatásban?
}

\section{Márkus Éva}

Eötvös Loránd Tudományegyetem Tanító- és Óvóképző Kar, Budapest

\begin{abstract}
A tanulmány bemutatja a német nyelvjárás megjelenését az általános iskola alsó tagozatán a hivatalos, új nemzetiségi kerettantervekben, helyi tantervekben és egyéb oktatással kapcsolatos dokumentumokban (2012. évi EMMI-rendelet a nemzetiség óvodai nevelésének irányelve és a nemzetiség iskolai oktatásának irányelve kiadásáról; Gyökerek és szárnyak. A magyarországi németek nevelési, oktatási és közmüvelődési programja, 2010). A szerző bemutat továbbá néhány lehetőséget a német nyelvjárás közvetítésének lehetőségére, illetve ismertet felhasználható irodalmi, módszertani és tudományos müveket.
\end{abstract}

Kulcsszavak: német nyelvjárások, nemzetiségi oktatás, alsó tagozat, kerettantervek, helyi tantervek

Jelen tanulmány arra vállalkozik, hogy megvizsgálja az általános iskola alsó tagozatán a német nyelvjárások szerepét - a hivatalos dokumentumok elemzése alapján -, és a nyelvjárás közvetítésének lehetséges útjait a nemzetiségi oktatásban. A nyelvelsajátítás, nyelvoktatás kapcsán a magyarországi németek esetében felmerül a 'háromnyelvüség' fogalma: három nyelv alatt értjük a magyar nyelvet, a német köznyelvet és a német nyelvjárást. 1945 előtt minden magyarországi német településen a kommunikáció nyelve a helyi nyelvjárás volt. Ezek a nyelvjárások gyakorlatilag minden falura egyedileg jellemző nyelvváltozatok, melyek jórészt a XVIII. századi betelepítések után alakultak ki. A német köznyelvvel a gyermekek 1945 előtt csak az iskolában, a tanítás során találkoztak. Mára ez a helyzet alapvetően megváltozott. Az iskolába kerülő német nemzetiségű gyermekek túlnyomó többségükben magyar nyelven szocializálódnak a családjukban, így az iskolára hárul az a feladat, hogy a német köznyelvet második nyelvként/nemzetiségi nyelvként vagy idegen nyelvként megtanítsa nekik. A nyelvjárásokkal való ismerkedés is része azonban a tanulmányaiknak, mert ez segíti a nemzetiségi identitásuk kialakítását.

A magyarországi nemzetiségek iskoláinak a 2012. évi EMMI-rendelet a nemzetiség óvodai neveléséne irányelve és a nemzetiség iskolai oktatásának irányelve kiadásáról ${ }^{1}$ szerint három típusát különböztetjük meg: 1. Anyanyelvű iskolák (a magyar nyelv és irodalom, valamint az idegen nyelv kivételével az oktató és nevelő munka a nemzetiség nyelvén folyik), 2. kétnyelvű iskolák (a pedagógiai program által meghatározott legalább három tantárgyat a nemzetiség nyelvén kell oktatni [az anyanyelv és irodalom mellett], összesen a heti kötelező órakeret magyar nyelv és irodalom és idegen nyelv óraszámával csökkentett számának legalább $50 \%$-ában) és 3. nyelvoktató típusú iskolák. A nyelvoktató nemzetiségi nevelés-oktatás hagyományos és bővített nyelvoktató formában valósítható meg. A hagyományos nyelvoktató nemzetiségi nevelés-oktatásban a tanítás nyelve a magyar nyelv, a nemzetiségi nyelv és irodalom tantárgyat tanítási óra keretében az első évfolyamtól kell tanítani. A bővített nyelvoktató nemzetiségi nevelés-

\footnotetext{
1 http://net.jogtar.hu/jr/gen/hjegy_doc.cgi?docid=A1300017.EMM
} 
oktatás célja a kétnyelvű nemzetiségi vagy az anyanyelvű oktatási formára való felkészítés. A nemzetiségi nyelv és irodalom tanulása, továbbá a nemzetiség nyelvén való tanulás egyidejüleg folyik, legalább három tantárgy nemzetiségi nyelven való tanulását kell lehetővé tenni, a nemzetiségi nyelv és irodalom, valamint a nemzetiségi nyelvű órák aránya a heti órakeret legalább 35\%-át teszi ki.

A magyarországi németek számára kétnyelvű és nyelvoktató típusú iskolák léteznek. Esetükben a nyelvelsajátítás, nyelvoktatás kapcsán - a tragikus, második világháborút követő események miatt - nem beszélhetünk anyanyelvi oktatásról, hanem a németet mint második nyelvet/nemzetiségi nyelvet vagy mint idegen nyelvet tanulják. A 2010-ben kiadott Gyökerek és szárnyak. A magyarországi németek nevelési, oktatási és közmüvelődési programja című dokumentum is megfogalmazza: „A német nyelv magas szintü ismerete, a helyi nyelvjárások és szokások ápolása, az ismeretek és eszmecserék a magyarországi németek történetéről és jelenéről a német nyelvterület modernkori kultúrájának ismeretével együtt a magyarországi német identitás nélkülözhetetlen részét képezi." (Erb és $m$ tsai, 2010. 8. o.)

A fent említett 2012. évi EMMI-rendelet a nemzetiségi népismeret nevü önálló tantárgy általános témakörei között sorolja fel a nyelvhasználati sajátosságokat, beleértve a nyelvjárásokat, nyelvváltozatokat.

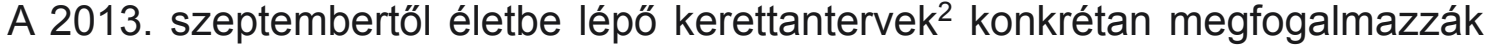
a nyelvjárások szerepét a nemzetiségi oktatásban. A német népismeret tantárgy kerettanterve szerint a „nyelv magas szintủ birtoklása, a helyi nyelvjárások és szokások ápolása, a történelem és a jelen ismerete - mindezek az identitás nélkülözhetetlen részét képezik". Az 1-2. évfolyamon a Személyes életvitel, szociális kapcsolatok - A család címú tematikai egységen belül ismeretként megjelenik a nyelvjárási és irodalmi német kifejezések megkülönböztetése a tárgyalt témában. A Gazdaság, technika, környezet - Az otthon és környezete címü tematikai egységen belül szintén ismeretként megjelenik a nyelvjárási és irodalmi német kifejezések egymás mellé állítása és a témához kapcsolódó, néhány gyakran használt nyelvjárási kifejezés ismerete. Csakúgy, mint a Gazdaság, technika, környezet - Közlekedés és a Gazdaság, technika, környezet - Háziállatok címü tematikai egységek esetében, ahol ismeretként jelenik meg a témához kapcsolódó, néhány gyakran használt nyelvjárási kifejezés. $\mathrm{A}$ 3-4. évfolyamon a Személyes életvitel - Szociális kapcsolatok című tematikai egységen belül ismeretként jelenik meg a nyelvjárási és irodalmi német kifejezések egymás mellé állítása, míg a Személyes életvitel - Öltözködés címü tematikai egységen belül pedig a nyelvjárási és irodalmi német kifejezések megtanulása. A Gazdaság, technika, környezet - Tájékozódás saját környezetben című tematikai egységen belül elvárásként fogalmazódik meg a témához kapcsolódó, néhány gyakran használt nyelvjárási kifejezés megismerése, használata. A nyelvjárást illető fejlesztés várt eredménye a 3-4. évfolyam végén: a tanulók megértik a lakóhelyükön gyakran használt nyelvjárási kifejezéseket.

A német nyelv és irodalom tantárgy 2013-tól életbe lépő kerettanterve a kétnyelvű nemzetiségi nevelési-oktatási forma számára alsó tagozaton megfogalmazza: „A nyelv magas szintű birtoklása, a helyi nyelvjárások és szokások ápolása, a történelem és jelen ismerete - mindezek az identitás nélkülözhetetlen részét képezik" (ibid.). Az 1-2. évfolyamon a Nyelvtani és nyelvhelyességi kompetencia; Kiejtés és hangsúlyozás tematikai egység/fejlesztési célon belül nevelési-fejlesztési célként megjelenik a

\footnotetext{
${ }^{2}$ http://www.udpi.hu/hu/dokumentumok/kerettantervek/kerettantervek-2013-szeptembertol
} 
„helyi német nyelvjárás kiejtési sajátosságainak megismertetése”. Követelményként jelenik meg: „néhány gyakran használt kifejezést, mondókát a helyi német nyelvjárásban megközelítően helyesen kiejteni és hangsúlyozni”. A 3-4. évfolyamon szintén a Nyelvtani és nyelvhelyességi kompetencia; Kiejtés és hangsúlyozás tematikai egység/fejlesztési célon belül nevelési-fejlesztési célként ismét megjelenik a „helyi német nyelvjárás kiejtési sajátosságainak megismertetése”. Követelményként ismételten a következőket találjuk: „néhány gyakran használt kifejezést, mondókát a helyi német nyelvjárásban megközelítően helyesen kiejteni és hangsúlyozni”. A nyelvjárás ezen a két évfolyamon már kulcsfogalomként is szerepel a megjelölt tematikai egységen belül.

A német nyelv és irodalom tantárgy 2013-tól életbe lépő kerettanterve szerint a nyelvoktató és a bővített nyelvoktató nemzetiségi nevelés-oktatás számára alsó tagozaton a Nyelvtani és nyelvhelyességi kompetencia tematikai egység/fejlesztési célon belül kapcsolódási pontként van megadva a német népismeret: rövid rímes szövegek nyelvjárási kifejezései. A Közismereti témák tematikai egység/fejlesztési célon belül pedig ismeretként jelenik meg a nyelvjárás: „Német nyelv: az egyes témákkal kapcsolatos néhány helyi nyelvjárási kifejezés". Egyes témák alatt a következők értendők: Személyes életvitel: A család, napirend, testápolás. Társadalmi élet: Étkezés, családi ünnepek, születésnap. Iskola, képzés, hivatás: Tantárgyak, osztályterem, olvasás, képregények, nemzetiségi gyermekjátékok. Kulturális élet és média: tv, számítógép, magyarországi német táncok, dalok, népi játékok. Környezet, gazdasági élet, technika: Otthon, települések, a magyarországi németek települései, épületek, természet, évszakok, időjárás. Politika és történelem: Együttmüködés, szerepek, az együttélés szabályai az osztályon és iskolán belül, munkamegosztás, a német nemzetiség mindennapjai.

A Magyarországi Németek Pedagógiai Intézete (UDPI) honlapján megjelent helyi tantervek 2015 szeptemberétől elnevezésű anyagokban megvizsgálva a nyelvjárás megjelenését, a következő dolgok derülnek ki: Sem a nyelvoktató sem a kétnyelvü típusú iskolák 1., 3. és 4. osztályában nem jelenik meg a nyelvjárás. A 2. osztályban a kompetenciák között szerepel, hogy a tanuló tudjon a helyi nyelvjárásban néhány szót, kifejezést, rímet érthetően kimondani és intonálni. A kétnyelvű oktatási formában 2. osztályban ugyanezt a megfogalmazást találjuk a kompetenciák között.

A kerettantervek is ajánlják a következő köteteket, amelyekből a pedagógusok könnyedén és jól felkészülhetnek a nyelvjárási tartalmak megismertetésére - föleg mondókákon és rímeken, verseken, dalokon, gyermekjátékokon keresztül: „Katharina Wild-Regine Metzler: Hoppe, hoppe Reiter; Grete und Karl Horak: Kinderlieder, Reime und Spiele der Ungarndeutschen; Igele-Bigele; Josef Michaelis: Zauberhut". Ezeken túl jól használható nyelvjárási mesekötet az Angela Korb gondozásában 2011ben, Budapesten megjelent Reigöd vum Weidepam. Kaanr Vrzäh/stickr von Mathilde Geiszkopf. A kötetben a Baranya megyei Kán településröl származó meséket találunk, CD-melléklettel és négy oldalas nyelvjárási szómagyarázattal a kötet végén, alfabetikus sorrendben.

A nyelvjárási kifejezések (például az előírt család, otthon, állatok, öltözködés stb. témakörében) elsajátíttatása céljából a saját gyűjtés kínálkozik megfelelő módszerként, ha módunk van rá és megtehetjük, mert találunk még olyan idős adatközlőt, aki segítségünkre van. Ennek előnye, hogy a nemzetiségi oktatás helyszínének nyelvjárását gyüjtjük le, nem szorulunk arra, hogy más település nyelvjárási kifejezéseit ismertessük meg a diákjainkkal. Hangfelvételeket is készíthetünk, így a kiejtést is „tiszta forrásból” ismerhetik meg a tanulók. Erre példa az ELTE TÓK egy lelkes hallgatója, Magyari Emese, aki nagymamájánál gyűjtött nyelvjárási kifejezéseket zöldség, gyümölcs, 
tejtermékek, konyhai edények stb. témakörben, melyeket rögzített is diktafonnal. Egy TDK-dolgozat témájaként évfolyamtársával, Brabanti Barbarával játékos feladatokat is kidolgoztak ezen nyelvjárási kifejezések gyermekbarát közvetítésére, amiket nagy sikerrel próbáltak ki a nemesnádudvari és a pilisvörösvári általános iskola alsó tagozatán, szakköri, illetve iskolai órák keretében. Egy továbbképzés során kiderült, hogy a szakmában dolgozó pedagógusok körében nagy igény mutatkozik a nyelvjárási anyagokra, szógyüjteményekre, hangfelvételekre.

Néhány településen már vannak kész szógyűjtemények, szólisták, melyeket szintén használhatunk az alsó tagozatos nemzetiségi oktatásban a nyelvjárási kifejezések megismertetése céljából. Példaként ide sorolható a vaskúti németek tájszólásának szótára, a Wörterbuch des Dialektes der Deutschen in Vaskut, Paul Schwalm tollából, mely 1979-ben jelent meg Münchenben, 405 oldalon. Ennél rövidebb tematikus szólisták találhatók a Katharina Wild: Zur komplexen Analyse der 'Fuldaer' deutschen Mundarten Südungarns címü kötet (megj. 2003, Budapest) 4. fejezetében, valamint a Márkó néphagyományai címü kötetben, Szilágyi-Kósa Anikó cikkében, itt megtaláljuk a rokonsági elnevezéseket, a hét napjait vagy a számneveket. Utóbbi kötet 2010-ben jelent meg, Veszprémben. A Bánd története II. kötetében (írta és szerkesztette Mádl Antal) találunk szólásokat, közmondásokat is (Therese Krein-Mádl összeállításában), de kiemelendő a majd 100 oldalas „szószedet Bánd szókincséből”, alfabetikus sorrendbe szedve. A kötet „Így éltek és beszéltek őseink” alcímmel jelent meg 2008-ban, Bándon. Hasonló példákat szerencsére szép számmal sorolhatnánk még. Vannak olyan gyűjtések is, melyek egyelöre kéziratos formában várnak a megjelenésre, mint például Juhász Márta PhD doktori disszertációja (2009, Budapest ELTE Germanisztikai Doktori Iskola) Die Mundart von Csolnok/Tscholnok címmel, amely szintén tartalmaz nyelvjárási szólistákat. Másik példaként Kiss Szilvia Siedlungsgeschichte und Dialekt in vier Dörfern des Bakony-Gebirges című PhD doktori disszertációja (2002, Budapest ELTE Germanisztikai Doktori Iskola) említhető.

Követendő példaként emelem ki a 2009-ben, Budapesten megjelent, Kriaz kaut! Grüß Gott! Ein Werischwarer Dialektbuch címủ három nyelvü, német köznyelvi, német nyelvjárási és magyar nyelvü kötetet, mely remek példája egy pedagógusokat segítő német nyelvjárási tananyagnak. Több ilyen mủnek kellene elkészülnie, gyakorlatilag minden magyarországi német település számára kellene, hogy létezzen egy ilyen nyelvjárási tankönyv. A szerzők, Andrusch-Fóti Mária és Müller Márta a tanítás tíz hónapjához igazodva dolgoztak ki tíz különböző témát, melyekhez nyelvjárási szavakat, mondatokat is megadnak. A könyvecskéhez CD-melléklet is tartozik, amely tartalmazza a nyelvjárási anyagot és annak német köznyelvi fordítását. A könyvben találunk ezen kívül szövegeket, történeteket, énekeket, mondókákat és játékokat is. Minden leckét egy magyarul megfogalmazott helytörténeti szöveg zár, amiben pilisvörösvári szokásokról, ünnepekröl esik szó. Bővebben a könyvről lásd Müller és Knipf-Komlósi, 2012. 217f., valamint a keletkezése körülményeiről és a felépítéséröl: Müller, 2010. 651f.

Frank Gábor, Elfi Fritsche, Hock Ibolya, Manz Alfred, Schäffer István, Walter Sottsas és Staub Ildikó jegyzik szerzőként a 2001-ben megjelent Geschichte und Gegenwart, Brauchtum und Sprache. Arbeitsmaterialien für den Unterricht an deutschen Nationalitätenschulen in Ungarn című kitűnő, színes oktatási segédanyagot. A mappa 'Zur Sprache der Ungarndeutschen' címü fejezetében jól használható játékos feladatokat találunk a nyelvjárással való ismerkedéshez. A mappához hangkazetta is tartozik, német nyelvjárási felvételekkel Magyarország különböző részeiről.

Remekül használható még a nyelvjárással történő foglalkozásokhoz az Ungarndeutscher Sprachatlas (UDSA) Südungarn, a Magyarországi Német Nyelvatlasz is, ed- 
dig a délnyugat-magyarországi terület anyaga látott napvilágot, két vaskos, nagy alakú kötetben. A színes térképek alkalmat kínálnak arra, hogy a diákok megéljék a nyelvjárások sokszínűségét, például a szentjánosbogárra a következő megnevezéseket találjuk a kötetben: Junikäfer, Brühvögel, Zündwürmchen, Feuerwürmchen, Lichtwürmchen, Nachtleuchter, Schmalzahnel, Herrgottslichtli vagy Herrgottsschupperchen. Az egyes településeket számok jelölik, a számokhoz a térképpel ellentétes oldalon található a szöveges hozzárendelés. Az atlasz I. félkötetéből kigyűjthetők például a következő állatnevek: Biene, Elster, Eidechse, Fledermaus, Fliege, Geiß, Goldamsel, Glühwürmchen, Hahn, Henne, Krähe, Libelle, Pferd, Stute, Füllen, növénynevek: Apfel, Bohne, Brennnessel, Brombeere, Erbse, Erdbeere, Eiche, Flieder, Fichte, grüne Bohnen, Himbeere, Kirsche, Kürbis, Pfirsich, Pappel, Stachelbeere, Tanne, Weidenbaum, ételek neve: Brot, Butter, Dotter, Strudel, Torte, Pogatscherl és a család témakör szavai: Bursche, Bube, Junge, Base, Frau, Freund, Mutter, Vater, Großmutter, Großvater, Tochter, Sohn, Pate, Patin, Schwester, Bruder. A kötet 134 település anyagát tartalmazza Tolna, Baranya, Somogy megyéböl és Észak-Bácskából. A területen nagyrészt középnémet nyelvjárásokat beszélő településeket találunk.

\section{Összegzés}

A tanulmány arra vállalkozott, hogy bemutassa a német nyelvjárás megjelenését alsó tagozaton a hivatalos, új nemzetiségi kerettantervekben. Ezek után bemutatott néhány lehetőséget a német nyelvjárás közvetítésére, a teljesség igénye nélkül. A cikk szerzője arra buzdít minden nemzetiségi pedagógust, hogy vonja be bátran a nyelvjárást is a német nemzetiségi nyelv oktatásába, mert ezzel felbecsülhetetlen kincset ad tanítványai kezébe.

\section{Felhasznált irodalom}

17/2013. (III. 1.) EMMI rendelet a nemzetiség óvodai nevelésének irányelve és a nemzetiség iskolai oktatásának irányelve kiadásáról.

URL: http://net.jogtar.hu/jr/gen/hjegy_doc.cgi?docid=A1300017.EMM. Letöltés ideje: 2014. 07. 31.

Andrusch-Fóti, M. \& Müller, M. (2009): Kriaz kaut! Grüß Gott! Ein Werischwarer Dialektbuch. Budapest.

Brabanti, B. \& Magyari, E. (2013): Zur Geschichte und Volkskunde der Dörfer Nadwar/ Nemesnádudvar und Neuhartin/ Újhartyán. Spielerische Methoden im Nationalitätenunterricht. TDK-dolgozat. Kézirat. Budapest.

Brenner, K. \& Erb, M. \& Manherz, K. (2008, Hgg.): in Zusammenarbeit mit H. J. Dingeldein: Ungarndeutscher Sprachatlas (UDSA) Südungarn. Erster Halbband: Budapest.

Erb, M., Englenderné Hock, I., Heltainé Panyik, E., Heves, F., Klein, Á., Knáb, E., Manz, A., Manzné Jäger, M., Müller, M., Rainer, P., Seiler, H. \& Szauer, Á. (2010): Gyökerek és szárnyak. A magyarországi németek nevelési, oktatási és közmüvelődési programja. Budapest.

Erb, Mária (2012). Ungarndeutscher Sprachatlas (UDSA) Südungarn. Zweiter Halbband. Budapest.

Frank, G. \& Fritsche, E. \& Hock, I. \& Manz, A. \& Schäffer, I. \& Sottsas, W. \& Staub, I. (2001): Geschichte und Gegenwart, Brauchtum und Sprache. Arbeitsmaterialien für den Unterricht an deutschen Nationalitätenschulen in Ungarn. Budapest.

Horak, G. \& Horak, K. (1988): Kinderlieder, Reime und Spiele der Ungarndeutschen. Budapest. (= Ungarndeutsche Studien 2.)

Juhász, M. (2009): Die Mundart von Csolnok/Tscholnok. Sprachsystem einer ungarndeutschen Varietät. PhD-doktori disszertáció. Kézirat. ELTE Germanisztikai Doktori Iskola, Budapest. 
Kerettantervek 2013 szeptembertöl.

URL: http://www.udpi.hu/hu/dokumentumok/kerettantervek/kerettantervek-2013-szeptembertol. Letöltés ideje: 2013. 07. 30.

Kiss, Sz. (2002): Siedlungsgeschichte und Dialekt in vier Dörfern des Bakony-Gebirges (Olaszfalu, Esstergart/Nagyesztergár, Rossbrunn/Lókut, Osslop/Bakonyoszlop). PhD doktori disszertáció. Kézirat. ELTE Germanisztikai Doktori Iskola, Budapest.

Koch, V. (1980, Hg.):. Igele Bigele. Ungarndeutsche Kinderanthologie. Budapest.

Korb, A. \& Schuth, J. (2011, Hg.): Reigöd vum Weidepam. Kaanr Vrzählstickr von Mathilde Geiszkopf. Budapest.

Mádl Antal (2008, szerk.): Bánd története II. Így éltek és beszéltek öseink. Bánd.

Márkusné Vörös Hajnalka (2010, szerk.): Márkó néphagyományai. Veszprém.

Michaelis, Josef (1994): Zauberhut. Budapest.

Müller Márta (2010): Möglichkeiten und Grenzen der Dialekterhaltung in einer ungarndeutschen Gemeinde. In: Zimányi Árpád (szerk.), A tudomány nyelve - a nyelv tudománya. MANYE Vol. 6. MANYE - Eszterházy Károly Főiskola, Székesfehérvár - Eger, 651-658.

Müller, M. \& Knipf-Komlósi, E. (2012): Mundarten im Minderheitenunterricht in ungarndeutschen Schulen. In Glauninger, M. - Barabas, B. (Hg.): Wortschatz und Sprachkontakt im Kontext oberdeutscher Wörterbücher, Sprachatlanten und Sprachinseln. Werner Bauer zum 70. Geburtstag \& Ortsgrammatiken als Unterrichtsbehelf: „Laiengrammatiken” für Minderheitensprachen. Wien, 209-222.

Schwalm P. (1979): Wörterbuch des Dialektes der Deutschen in Vaskut. München.

Szilágyi-Kósa, A. (2010): Márkó nyelvjárása és tulajdonnevei. In: Márkusné Vörös Hajnalka (szerk.): Márkó néphagyományai. Veszprém, 233-295.

Wild, K. \& Metzler R. (1982): Hoppe, hoppe Reiter. Reime, Lieder und Spiele aus der Baranya. Budapest.

Wild, K. (2003): Zur komplexen Analyse der 'Fuldaer' deutschen Mundarten Südungarns. Budapest.

www.udpi.hu/index.php?pageid $=8$ Ungarndeutsches Pädagogisches Institut honlapja. Letöltés ideje: 2013. 07. 30.

http://www.udpi.hu/hu/dokumentumok/kerettantervek/helyi-tantervek-2015-szeptemberetol Letöltés ideje: 2015. 10. 15. 